\title{
Synchronous subungual glomus tumors in the same finger *
}

\author{
Tumores glômicos subungueais sincrônicos no mesmo dedo
}

\author{
Nilton Di Chiacchio ${ }^{1}$ \\ Nilton Gioia Di Chiacchio ${ }^{3}$
}

\author{
Walter Refkalefsky Loureiro² \\ Diego Leonardo Bet ${ }^{3}$
}

\begin{abstract}
The glomus tumor is an uncommon benign neoplasm of glomus cells. In the majority of the cases it is presented as a solitary painful papule in the subungual region. We report a rare case of a patient with two individual synchronous glomus tumors under the nail bed of the same finger.

Keywords: Glomus tumor; Nail diseases; Nails; Neoplasms, multiple primary; Surgical procedures, minor

Resumo: O tumor glômico é uma neoplasia benigna de células glômicas. Na maioria dos casos se apresenta como uma pápula solitária dolorosa na região subungueal. Relatamos o caso raro de um paciente com dois tumores glômicos sincrônicos sob o leito ungueal do mesmo dedo.

Palavras-chave: Doenças da unha; Neoplasias primárias múltiplas; Procedimentos cirúrgicos menores; Tumor glômico; Unhas
\end{abstract}

\section{INTRODUCTION}

The glomus tumor is an uncommon benign neoplasm of glomus cells, which are modified smooth muscle cells mostly found in arterio-venous anastomoses of the extremities. They represent $1-5 \%$ of all soft tissue tumors of the hands, are more prevalent in adult women around the $3^{\text {rd }}$ or $5^{\text {th }}$ decade of life and considered a rare entity in childhood ${ }^{1}$. Clinically it appears as a small solitary nodule located in the hands in up to $75 \%$ of the patients, most of them in the fingers. ${ }^{1,2,3}$ Multiple glomus tumors are present in approximately $10 \%$ of the cases, with $90 \%$ presenting in the extremities before the age of $20^{2}$. The classical symptom triad is paroxysmal pain (80\%), local hyperalgia (100\%) and temperature sensibility to cold (63\%), important diagnostic features in more than $90 \%$ of the patients ${ }^{3}$. The differential diagnoses are painful or bluish/red lesions: implantation cysts, neuromas, subungual horns, foreign bodies, leiomyoma, blue rubber bleb nevus, blue nevi and hematomas. The treatment of choice is surgical excision with classic and innovative approaches in the literature. ${ }^{4,5}$ Recurrence is not uncommon and is more frequent in skin colored lesions within the nail matrix region. ${ }^{6}$

Opposed to the glomus tumors, glomangiomas are usually multiple, non capsulated and have a histopathologic appearance of hemangioma.

We describe a rare case of 2 synchronous glomus tumors occurring simultaneously under the nail bed of the same finger.

\section{CASE REPORT}

We report a case of a 32 years old male patient born in São Paulo - Brazil and resident in Nagoya Japan. He was admitted to our private clinic with pain in the extremity of the $3^{\text {rd }}$ left finger for 18 months. The symptoms were aggravated by cold exposure and minor traumas to the nail plate. There was no previous history of local injuries or medications in use.

The finger exam revealed through the nail plate two pale blue colored lesions, one central near the

Received on 22.03.2011.

Approved by the Advisory Board and accepted for publication on 20.08.2011.

* Study carried out at the Municipal Public Worker Hospital of São Paulo (Hospital do Servidor Público Municipal de São Paulo - HSPM) - São Paulo (SP), Brazil Conflict of interest: None / Conflito de interesse: Nenbum

Financial funding: None / Suporte financeiro: Nenbum

PhD in Dermatology - Head of the Dermatology Department, Municipal Public Worker Hospital of São Paulo (Hospital do Servidor Público Municipal de São Paulo - HSPM) - São Paulo (SP), Brazil.

Specialist in Dermatology - Volunteer physician of the Dermatology Department, Municipal Public Worker Hospital of São Paulo (Hospital do Servidor Público Municipal de São Paulo - HSPM) - São Paulo (SP), Brazil.

Physician undergoing specialization training - Intern at the Dermatology Service of the Teaching Hospital of Taubaté - Taubaté University (Universidade de Taubaté - HUT - UNITAU) - Taubaté (SP), Brazil. 
lunula and the other distal, close to the byponychium (Figure 1). Nail dystrophy was not observed. Love's test was found to be positive by pressuring the tip of a paper clip over each of the blue spots. Pain was alleviated by insufflating a blood pressure cuff at the patients wrist (positive Hildreth's test). Pain could also be induced with a gloved ice cube placed over the nail plate, which subsided promptly when the finger was submerged in lukewarm water.

Due to the patient's economic limitations, we did not perform any image study prior to the surgery. The nail plate was completely removed after distal block anesthesia with lidocaine and tourniquet placement. We observed two distinct pale blue papules measuring 2 to $3 \mathrm{~mm}$ covered by normal nail bed tissue (Figure 2). Using a transversal incision $1 \mathrm{~mm}$ distal and parallel to the lunula, the proximal lesion was exposed. The distal papule was approached by a longitudinal nail bed incision. The capsulated tumors were then dissected and removed (Figure 3). Primary nail bed closure with absorbable 6-0 Catgut was realized and the nail plate was placed back as a biological dressing. The histopathological exam confirmed the diagnosis of glomus tumor in both lesions. Two months later the patient was contacted by e-mail and referred normal nail growth and no pain.

\section{DISCUSSION}

The subungual glomus tumor is frequently seen as a solitary lesion. In a Brazilian retrospective study of 13 years, all the patients presented with only one lesion. ${ }^{1}$ Synchronous lesions are extremely rare and they were reported in adjacent digits, nonadjacent digits, multiple finger joints or in the pulp and subungual region. ${ }^{7-10}$ In our patient, both tumors were simultaneously subungual and, to our knowledge, it may be considered as the first report of such a rare presentation.

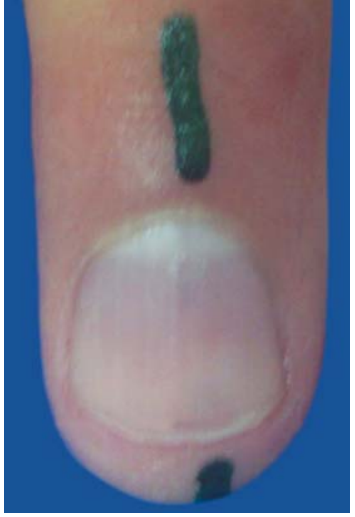

Figure 1: Blue lesions under the nail plate

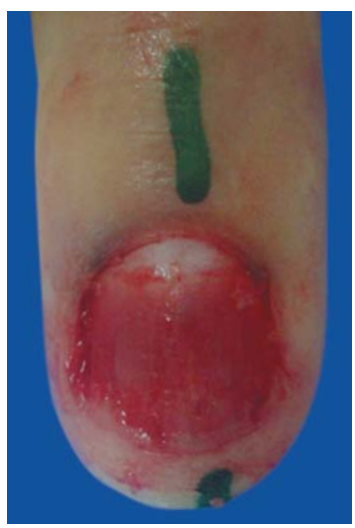

Figure 2:

Tumors on the nail bed

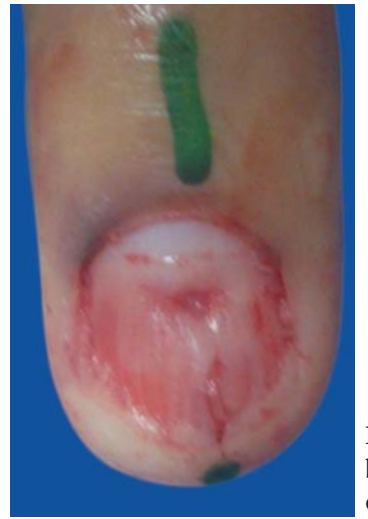

Figure 3: Nail bed after tumors excision

\section{REFERENCES}

1. Vanti AA, Cucé LC, Chiacchio ND. Tumor glômico subungueal: estudo epidemiológico e retrospectivo, no período de 1991 a 2003. An Bras Dermatol. 2007;82:425-31.

2. Anakwenze OA, Parker WL, Schiefer TK, Inwards CY, Spinner RJ, Amadio PC. Clinical features of multiple glomus tumors. Dermatol Surg. 2008;34:884-90.

3. Carroll RE, Berman AT. Glomus tumors of the hand: review of the literature and report on twenty-eight cases. J Bone Jt Surg. 1972;54:691-703.

4. Vasisht B, Watson HK, Joseph E, Lionelli GT. Digit glomus tumor: a 29-year experience with a lateral subperiosteal approach. Plast Reconstruct Surg. 2004;114:1486-9

5. Roan TL, Chen CK, Horng SY, Hsieh JH, Tai HC, Hsieh MH, et al. Surgical technique innovation for the excision of subungual glomus tumors. Dermatol Surg 2011;37:259-62.

6. Lin YC, Hsiao PF, Wu YH, Sun FJ, Scher RK. Recurrent digital glomus tumor: anaIysis of 75 cases. Dermatol Surg. 2010;36:1396-400.

7. Graham B, Wolf TW. Synchronous subungueal glomus tumors in adjacent digits. J Hand Surg. 1992;17B:575-6.
8. Rimington TR, Lefton CS. Simultaneous solitary glomus tumors in nonadjacent digits. Am J Orthop. 2009;38:E82-4.

9. Nakamura K. Multiple glomus tumor associated with arteriovenous fistulas and with nodular lesions of the finger joints. Plat Reconstr Surg. 1992;90:675-83.

10. Noor MA, Masbah 0, Lumpur K. Synchronous glomus tumors in a distal digit: a case report. J Hand Surg Am. 1997;22:508-10.

How to cite this article: Di Chiacchio N, Loureiro WR, Di Chiacchio NG, Bet DL. Synchronous subungueal glomus tumors in the same finger. An Bras Dermatol. 2012;87(3):475-6. 